\title{
GROWTH, DEVELOPMENT AND FOLIARY ULTRASTRUCTURAL PARAMETERS OF DIFFERENT EUCALYPTUS GENETIC MATERIALS
}

\author{
Lucas Aparecido Manzani Lisboa ${ }^{1}$, Allan de Marcos Lapaz ${ }^{1}$, Thadeu Henrique Novais Spósito², Ronaldo da \\ Silva Viana ${ }^{1}$, Paulo Alexandre Monteiro de Figueiredo ${ }^{1}$ \\ ${ }^{1}$ São Paulo State University (Unesp), College of Agricultural and Technological Sciences, Dracena - lucas.lisboa@ unesp.br;
allanlapaz60@ gmail.com; ronaldo.viana@unesp.br; paulo.figueiredo@ unesp.br
${ }^{2}$ State Technical School Prof. Dr. Antônio Eufrásio de Toledo, Presidente Prudente - thadeusposito@ agronomo.eng.br
}

Received for publication:18/05/2017 - Accepted for publication:06/06/2018

\begin{abstract}
Currently eucalyptus is used as raw material in different industrial segments. The aim of this study was to evaluate the growth, development and ultrastructural parameters in different eucalyptus genetic materials. The randomized block experiment was carried out in ten treatments and five replicates, with different genetic materials: six hybrids:I-144; H-13; 110; NA-151; NA-189 (Eucalyptus urophilla S. T. Blake x Eucalyptus grandis W. Hill); Grancam 1277 (Eucalyptus grandis W. Hill x Eucalyptus camaldulensis Dehnh.); and four pure genetic materials:0020 (Eucalyptus saligna $\mathrm{Sm}$.); 0010 (Eucalyptus resinífera $\mathrm{Sm}$.); Eucalyptus pellita F. Muell. and Corymbia torelliana (F. Muell.) K. D. Hill \& L. A. S. Johnson.Approximately four years after planting, the following variables were determined: plant height (AP), diameter at breast height (DAP), spad index (ISPAD), adaxial cuticle thickness (ECAD), abaxial cuticle thickness (ADX), abaxial epidermal thickness (EEAB), xylem diameter (DX), phloem diameter (DF) and palisade parenchyma length (CPP). The materials NA - 151 (Eucalyptus urophilla x E. grandis) and Grancam 1277 (E. grandis x E. camaldulensis) presented higher plant height (AP). The materials 0020 (E. saligna); 0010 (E. resinifera) and Corymbia torelliana presented smaller diameter at breast height (DAP). In general, the Corymbia torelliana genetic material had the lowest values in the ultrastructural foliar parameters.

Keywords:Leaf morphology, Eucalyptus spp., Corymbia spp., genetical enhancement.
\end{abstract}

\section{Resumo}

Avaliação do crescimento, desenvolvimento e parâmetros ultraestruturas foliares em diferentes materiais genéticos de eucalipto. Atualmente, o eucalipto é utilizado como matéria-prima em diferentes segmentos industriais. Este trabalho teve por objetivo avaliar o crescimento, desenvolvimento e parâmetros ultraestruturais foliares em diferentes materiais genéticos de eucalipto. Foi instalado um experimento em blocos casualizados, com dez tratamentos e cinco repetições, constituídos por diferentes materiais genéticos, sendo: seis híbridos: I-144; H-13; 110; NA-151; NA-189 (Eucalyptus urophilla S. T. Blake x Eucalyptus grandis W. Hill); Grancam 1277 (Eucalyptus grandis W. Hill x Eucalyptus camaldulensis Dehnh.); e quatro materiais genéticos puros: 0020 (Eucalyptus saligna Sm.); 0010 (Eucalyptus resinífera Sm.); Eucalyptus pellita F. Muell. e Corymbia torelliana (F. Muell.) K. D. Hill \& L. A. S. Johnson. Aproximadamente quatro anos após o plantio, foram determinadas as seguintes variáveis: altura de planta (AP), diâmetro à altura do peito (DAP), índice spad (ISPAD), espessura da cutícula adaxial (ECAD), espessura da cutícula abaxial (ECAB), espessura da epiderme adaxial (EEAD), espessura da epiderme abaxial (EEAB), diâmetro de xilema (DX), diâmetro do floema (DF) e comprimento do parênquima paliçádico (CPP). Os materiais NA - 151 (Eucalyptus urophilla x E. grandis) e Grancam 1277 (E. grandis x E. camaldulensis) apresentaram maior altura de planta (AP). Os materiais 0020 (E. saligna); 0010 (E. resinífera) e Corymbiatorelliana apresentaram menor diâmetro à altura de peito (DAP). De maneira geral, o material genético Corymbiatorelliana apresentou os menores valores nos parâmetros ultraestruturais foliares.

Palavras-chave: Morfologia foliar ultrastructural parameters.

\section{INTRODUCTION}

Eucalyptus is a tree species belonging to the Myrtaceae family. It is used in various reforestation programs as a result of its rapid growth and good adaptation to different soil and climate conditions, favoring remnant native forest preservation. It is a widely used tree as raw material in different industrial segments linked to cellulose, paper, coal, among other sectors. In addition, its leaves have been used for essential oils extraction (FIGUEIREDO et al., 2011). Its leaves are evergreen, opposite and simple, with entire margins with oil glands (DONATO; MORRETES, 2009; BÜNDCHEN et al., 2015).

FLORESTA, Curitiba, PR, v. 49, n. 1, p. 021-030, jan/mar.2019

Lisboa.L.A.M. et.al.

Electronic ISSN 1982-4688

DOI: $10.5380 /$ rf.v49i1.52527 
The foliar morphoanatomic study is of great importance to know the species characteristics, since it is closely related to the plant biomass increase, as well as to the adaptability and available abiotic resources use (PIRES et al., 2015; ARAGÃO et al., 2014; JAMES; BELL, 2001). According to Trevisan et al. (2013), the study of the interaction of the leaves with wood quality and its respective volume must be cautious as the biotic and abiotic factors can influence cambial activity and, consequently, increase wood heterogeneity.

The species within the gender Eucalyptus L'Hér. may present genetic variability. According to Butler et al. (2017), it has been observed two little interchromosomal translocation between the species E. globulus Labill. and E. grandis W. Hill x hybrid of E. urophylla S. T. Blake. Thus, the proper choice of genetic material in breeding research is fundamental for more productive forests generation with adaptability in different regions, having greater resistance to biotic and abiotic factors. Between the species of this gender the ones that are more distinguish are E. grandis, E. urophylla, E. camaldulensis Dehnh., E. saligna Sm., and their interspecific hybrids, like "urograndis", which also stand out between the most planted.

The gender Corymbia K. D. Hill \& L. A. S. Johnson has been less researched than the gender Eucalyptus (HEALEY et al., 2016b).The species C. citriodora (Hook.) K. D. Hill \& L. A. S. Johnson, $C$. maculata (Hook.) K. D. Hill \& L. A. S. Johnson and, mainly, C. torelliana (F. Muell.) K. D. Hill \& L. A. S. Johnson have been growing in importance under the aspect of cross-breeding to obtain interspecific hybrids with high biomass production (REIS et al., 2014; BUTLER et al., 2017).

However, little is known about the differences of leaf ultra structural features of these species, making necessary to research and emphasize them, moving towards the best use of their genetic material. Considering this, this study aimed to evaluate the growth, development and foliar ultra structural parameters in different eucalyptus genetic materials.

\section{MATERIAL AND METHODS}

In March, 2013, for the accomplishment of the present study, it was selected an area in the State Technical School Prof. Dr. Antônio Eufrásio de Toledo, in the municipality of Presidente Prudente, state of São Paulo, with the following geographic coordinates $22^{\circ} 10^{\prime} 35,884^{\prime \prime} \mathrm{S}$ e $51^{\circ} 22^{\prime} 35,984^{\prime \prime} \mathrm{W}$ and $460 \mathrm{~m}$ of altitude. According to Köppen, the climate of the region is classified as Aw, with rainy summers and dry winters, and it presents average annual rainfall of $1.250 \mathrm{~mm}$. The area presents a terrain with approximate slope of 5\%, soil classified as Red Yellow Argisol (EMBRAPA, 2013).At the time of the experiment, the solo presented the following chemical characteristics: $\mathrm{pH}-\mathrm{CaCl}_{2} 6,0 ; \mathrm{MO} \mathrm{g} \mathrm{dm}{ }^{-3}-9.5 ; \mathrm{P} \mathrm{mg} \mathrm{dm}^{-3}$ (resin) - 8.0; $\mathrm{K} \mathrm{mmol}_{\mathrm{c}} \mathrm{dm}^{-3}$ (resin) - 1.7; $\mathrm{Ca} \mathrm{mmol}_{\mathrm{c}} \mathrm{dm}^{-3}$ (resin) - 51.0; $\mathrm{Mg} \mathrm{mmol}_{\mathrm{c}} \mathrm{dm}^{-3}$ (resin) - 7.3; $\mathrm{H}+\mathrm{Al} \mathrm{mmolc} \mathrm{dm}{ }^{-3}-11.6 ; \mathrm{Al} \mathrm{mmol}_{\mathrm{c}}$ $\mathrm{dm}^{-3}-0.0$; sum of bases $\mathrm{mmol}_{\mathrm{c}} \mathrm{dm}^{-3}-60.0$; CTC $\mathrm{mmol}_{\mathrm{c}} \mathrm{dm}^{-3}-71,6$; and bases saturation (V\%) - 83.8. Liming was performed in the total area. Soil preparation and fertilization in pits were made with 04-30-10 formulation (NPK), according to Raij et al. (1996).

In April 2013, the experiment in randomized blocks was installed, with ten treatments composed by five repetitions, totaling 50 plots with 20 eucalyptus plants. The treatments were constituted by different genetic materials, being six hybrids: I-144; H-13; 110; NA-151; NA-189 (Eucalyptus urophilla S.T. Blake x Eucalyptus grandis W. Hill); Grancam 1277 (Eucalyptus grandis W. Hill x Eucalyptus camaldulensis Dehnh.); and four pure genetic materials:0020 (Eucalyptus saligna $\mathrm{Sm}$.); 0010 (Eucalyptus resinífera $\mathrm{Sm}$.); Eucalyptus pellita $\mathrm{F}$. Muell. e Corymbia torelliana (F. Muell.) K. D. Hill \& L. A. S. Johnson.

The used spacing was of $3 \times 2 \mathrm{~m}$ with clonal seedlings of approximately 90 days of age deriving from the nursery of the Experimental Station of Forest Sciences (University of São Paulo), located in the municipality of Itatinga (SP).During the phases of growth and development of the plants in the field, the cultural and phytosanitary necessary treatments have been carried through.

In January 2017, when the plants had little less than four years, ten plants per plot were randomly selected to determine the following parameters: plant height (AP), determined through a digital clinometer ten meters away from the trunk; diameter at breast height (DAP), determined by means of direct reading with the help of a forest caliper, in centimeters; spad index (ISPAD), determined by means of direct reading of the digital meter CCM-200 model in leaves from the middle third of the plant.

Afterwards, random leaves were collected from the middle third of the plants of each plot to determine the leaf nitrogen tenor and morphoanatomical parameters. For the determination of foliar nitrogen tenor $(\mathrm{N})$, leaf samples of each treatment were subjected to drying in a forced convection and air exchange oven at $65^{\circ} \mathrm{C}$ until they reach constant weight. These samples were ground in rotating knives mill of Willey kind. Later, it was weighted 0.1 gram of each sample for digestion in sulfuric acid and determined the nitrogen tenor of those samples. 
For evaluation of ultra structural characteristics, leaf fragments were removed from the middle of limbo with about five centimeters in length and fixed in FAA 70 (37\% formaldehyde, $70 \%$ acetic acid and ethanol in the proportion of 1.0:1.0:18.0-V/V) for 24 hours. Then, they were washed and stored in $70 \%$ alcohol. The leaf fragments were sent to the Vegetable Morphophysiology and Forage-growing Laboratory of the Faculty of Agricultural and Technology Sciences of the São Paulo State University, located in the city of Walnut Creek, in São Paulo state, where they went through dehydration, cleaning, embedding and inclusion procedures, according to Krause Arduim (1997).

With the aid of a table microtome $8.0 \mu \mathrm{m}$ transversal sections were made in each embedded leaf fragment containing the leaf midrib. For each embedded material, it was mounted a histological slide. For this assembly, it was chosen the first transversal section that presented the most preserved material, i.e. without damage or injuries caused by cutting in the plant tissues. The chosen sections have been fixed with adhesive with albumin. The sections were stained with safranin at $1 \%$ and mounted on slide and cover slip with adhesive Entellan ${ }^{\circledR}$ (KRAUS; ARDUIM, 1997).

Measurements of leaf parameters were performed in the leaf's central vein. The blades were observed in an optical microscope Olympus ${ }^{\circledR}$, model BX43, containing a camera attached to take photographs of the cuts. The photographs were used for measurements of anatomical parameters by image analysis program cellSens Standard $^{\circledR}$, calibrated with the same microscopic ruler of photographs magnification.

Each experimental plot was represented by the average of 10 measurements of the analyzed parameters: thickness of adaxial cuticle (TADC), thickness of abaxial cuticle (TABC), adaxial epidermis thickness (ADET), abaxial epidermis thickness (ABET) diameter of xylem (DX), diameter of the phloem (DP) and Palisade cell length (PCL), according to Carlquist (1975).

In the data statistical analysis, the parameters were submitted to variance analysis by the $\mathrm{F}$ test $(\mathrm{p}<0.05)$ and their means compared by the Skott-Knott test at $5 \%$ probability. The statistical program used was the Assisat 7.6 Beta (SILVA; AZEVEDO, 2016).

\section{RESULTS}

In the plant height (AP), the materials that presented the highest averages were NA-151 (Eucalyptus urophilla $\mathrm{x}$ E. grandis) and Grancam 1277 (E. grandis x E. camaldulensis), respectively, while the other species did not differ from each other, as shown in Table 1.On the other hand, for the parameter diameter at breast height (DAP), the materials with the lowest mean values were: 0020 (E. saligna), 0010 (E. urophilla $\times$ E. grandis) and Corymbia torelliana, being this last species the one which showed the smallest value.

Table 1. Average values of plant height (AP), diameter at breast height (DAP), spad index (ISPAD) and nitrogen tenor $(\mathrm{N})$ of genetic material of the Eucalyptus and Corymbia genres, four years after planting.

Tabela 1. Valores médios de altura da planta (AP), diâmetro em altura de peito (DAP), índice de spad (ISPAD) e teor de nitrogênio (N) de material genético dos gêneros Eucalyptus e Corymbia, quatro anos depois de plantados. 


\begin{tabular}{|c|c|c|c|c|}
\hline & $\begin{array}{l}\text { AP } \\
(\mathrm{m})\end{array}$ & $\begin{array}{l}\text { DAP } \\
(\mathrm{cm})\end{array}$ & $\begin{array}{l}\text { ISPAD } \\
\text { (Unid.) }\end{array}$ & $\begin{array}{c}\mathrm{N} \\
(\%)\end{array}$ \\
\hline $\mathrm{I}-144$ & $15,26 b$ & $14,21 \mathrm{a}$ & $24,22 \mathrm{c}$ & $1,71 \mathrm{c}$ \\
\hline $\mathrm{H}-13$ & $14,60 \mathrm{~b}$ & $15,07 \mathrm{a}$ & $32,36 a$ & $2,21 b$ \\
\hline 110 & $15,46 b$ & $14,28 \mathrm{a}$ & $21,48 \mathrm{c}$ & $2,06 \mathrm{c}$ \\
\hline NA-151 & $19,34 \mathrm{a}$ & $16,25 \mathrm{a}$ & $33,88 \mathrm{a}$ & $2,55 \mathrm{a}$ \\
\hline NA-189 & $15,06 \mathrm{~b}$ & $14,41 \mathrm{a}$ & $17,18 \mathrm{c}$ & $1,85 \mathrm{c}$ \\
\hline Grancam 1277 & $18,40 \mathrm{a}$ & $14,65 \mathrm{a}$ & $27,30 b$ & $2,18 b$ \\
\hline 0020 & $14,58 b$ & $13,32 b$ & $21,62 \mathrm{c}$ & $1,66 \mathrm{c}$ \\
\hline 0010 & $16,10 b$ & $12,55 \mathrm{~b}$ & $25,22 \mathrm{c}$ & $2,01 \mathrm{c}$ \\
\hline E. pellita & $16,46 b$ & $13,82 \mathrm{a}$ & $29,32 b$ & $1,93 c$ \\
\hline C. torelliana & $12,57 b$ & $12,09 b$ & $21,12 \mathrm{c}$ & $1,81 \mathrm{c}$ \\
\hline $\mathrm{F}$ & $2,5977^{*}$ & $2,7634^{*}$ & $9,3448^{* * *}$ & $5,0176^{* *}$ \\
\hline $\mathrm{CV}(\%)$ & 17,11 & 11,54 & 15,39 & 13,49 \\
\hline MG & 15,78 & 14,07 & 25,37 & 2,00 \\
\hline \multicolumn{5}{|c|}{$\begin{array}{l}\text { **: significant at the level of } 1 \% \text { probability }(\mathrm{p}<0.01) \text {; *: significant at the level of } 5 \% \text { probability }(0.01=<\mathrm{p}<0.05) \text {; F: } \mathrm{f} \text { value calculated in } \\
\text { the variance analysis; CV: coefficient of variation; MG: overall average. The mean followed by the same letter does not differ statistically } \\
\text { between themselves by Scott-Knott test at } 5 \% \text { probability level. } \\
\text { **: significativo ao nível de } 1 \% \text { de probabilidade }(\mathrm{p}<0,01) \text {; *: significativo ao nível de } 5 \% \text { de probabilidade }(0,01=<\mathrm{p}<0,05) \text {; F: valor do } \mathrm{f} \\
\text { calculado na análise de variância; CV: coeficiente de variação; MG: média geral. As médias seguidas pela mesma letra não diferem } \\
\text { estatisticamente entre si pelo Teste de Scott-Knott ao nível de } 5 \% \text { de probabilidade. }\end{array}$} \\
\hline
\end{tabular}

With respect to the index spad (ISPAD) parameter, materials NA-151 (Eucalyptus urophilla x E. grandis) and H-13 (E. urophilla $\mathrm{x}$ E. grandis) presented the highest averages. For the leaf nitrogen tenor, just the material NA-151 (E. urophilla $\mathrm{x}$ E. grandis) showed the highest concentration of this element.

In the variable thickness of the adaxial cuticle (ECAD), Grancam 1277 materials (Eucalyptus grandis $\mathrm{x}$ E. camaldulensis), H-13 (E. urophilla $\mathrm{x}$ E. grandis), 0010 (E. resinifera) and E. pellita presented the best results as shown in Table 2. On the other hand, the thickness of the abaxial cuticle (ECAB), 0010 material (E. resinifera) presented the highest average.

Table 2. Average values of the thickness of the adaxial cuticle (ECAD), thickness of cuticle abaxial (ECAB), thickness of the adaxial epidermis (EEAD) and abaxial epidermis thickness (EEAB) of the genetic material of the genre Eucalyptus and Corymbia, four years after planting.

Tabela 2. Valores médios de espessura da cutícula adaxial (ECAD), espessura da cutícula abaxial (ECAB), espessura da epiderme adaxial (EEAD) e espessura da epiderme abaxial (EEAB) do material genético do gênero Eucalyptus e Corymbia, quatro anos depois de plantados.

\begin{tabular}{lcccc}
\hline & $\begin{array}{c}\text { ECAD } \\
(\mu \mathrm{m})\end{array}$ & $\begin{array}{c}\text { ECAB } \\
(\mu \mathrm{m})\end{array}$ & $\begin{array}{c}\text { EEAD } \\
(\mu \mathrm{m})\end{array}$ & $\begin{array}{c}\text { EEAB } \\
(\mu \mathrm{m})\end{array}$ \\
\cline { 2 - 5 } $\mathrm{I}-144$ & $3,93 \mathrm{~b}$ & $5,16 \mathrm{~b}$ & $12,97 \mathrm{~b}$ & $11,24 \mathrm{~b}$ \\
$\mathrm{H}-13$ & $4,79 \mathrm{a}$ & $4,47 \mathrm{~b}$ & $11,96 \mathrm{~b}$ & $12,51 \mathrm{a}$ \\
110 & $3,13 \mathrm{~b}$ & $3,39 \mathrm{~b}$ & $11,35 \mathrm{~b}$ & $9,44 \mathrm{~b}$ \\
NA-151 & $3,85 \mathrm{~b}$ & $4,39 \mathrm{~b}$ & $9,69 \mathrm{c}$ & $9,40 \mathrm{~b}$ \\
NA-189 & $3,59 \mathrm{~b}$ & $4,22 \mathrm{~b}$ & $9,73 \mathrm{c}$ & $10,48 \mathrm{~b}$ \\
Grancam 1277 & $5,45 \mathrm{a}$ & $4,63 \mathrm{~b}$ & $10,27 \mathrm{c}$ & $10,59 \mathrm{~b}$ \\
0020 & $3,48 \mathrm{~b}$ & $4,24 \mathrm{~b}$ & $11,81 \mathrm{~b}$ & $11,01 \mathrm{~b}$ \\
0010 & $4,57 \mathrm{a}$ & $6,51 \mathrm{a}$ & $11,12 \mathrm{~b}$ & $10,66 \mathrm{~b}$ \\
E. pellita & $4,96 \mathrm{a}$ & $4,76 \mathrm{~b}$ & $15,82 \mathrm{a}$ & $14,38 \mathrm{a}$ \\
C. torelliana & $3,92 \mathrm{~b}$ & $3,83 \mathrm{~b}$ & $6,92 \mathrm{~d}$ & $7,02 \mathrm{c}$ \\
\hline F & $4,0840^{* *}$ & $3,8143^{* *}$ & $7,3490^{* *}$ & $6,1225^{* *}$ \\
\hline CV $(\%)$ & 19,65 & 21,11 & 17,25 & 16,46 \\
\hline MG & 4,17 & 4,56 & 11,16 & 10,67 \\
\hline
\end{tabular}

**: significant at the level of $1 \%$ probability $(\mathrm{p}<0.01)$; *: significant at the level of $5 \%$ probability $(0.01=<\mathrm{p}<0.05)$; F: $\mathrm{f}$ value calculated in the variance analysis; CV: coefficient of variation; MG: overall average. The mean followed by the same letter does not differ statistically between themselves in the Scott-Knott test at $5 \%$ probability level.

**: significativo ao nível de $1 \%$ de probabilidade ( $<<0,01)$; *: significativo ao nível de $5 \%$ de probabilidade $(0,01=<\mathrm{p}<0,05)$; F: valor do $\mathrm{f}$ calculado na análise de variância; CV: coeficiente de variação; MG: média geral. As médias seguidas pela mesma letra não diferem estatisticamente entre si pelo Teste de Scott-Knott ao nível de 5\% de probabilidade.

FLORESTA, Curitiba, PR, v. 49, n. 1, p. 021-030, jan/mar.2019 
It is important to point out that only the material Corymbia torelliana presented the minor averages for the parameters of thickness of the adaxial epidermis (EEAD) and thickness of the abaxial epidermis (EEAB) (Table 2).

In the parameter diameter of xilema (DX), statistics difference was verified, where the H-13; 110, NA189 and Corymbia torelliana materials had presented the minor average, while in the phloem diameter (DF), only C. torelliana presented the lesser value, as demonstrated in Table 3.

Table 3. Average values of the diameter of xilema (DX), phloem diameter (DF) and length of palisade cell (CPP) of the genetic materials of the genera Eucalyptus and Corymbia, four years after the plantating.

Tabela 3. Valores médios de diâmetro do xilema (DX), diâmetro do floema (DF) e comprimento da célula paliçada (CPP) dos materiais genéticos dos gêneros Eucalyptus e Corymbia, quatro anos após o plantio.

\begin{tabular}{lccc}
\hline & $\begin{array}{c}\text { DX } \\
(\mu \mathrm{m})\end{array}$ & $\begin{array}{c}\text { DF } \\
(\mu \mathrm{m})\end{array}$ & $\begin{array}{c}\text { CPP } \\
(\mu \mathrm{m})\end{array}$ \\
\cline { 2 - 3 } I-144 & $19,57 \mathrm{a}$ & $6,79 \mathrm{a}$ & $51,77 \mathrm{a}$ \\
$\mathrm{H}-13$ & $17,62 \mathrm{~b}$ & $5,05 \mathrm{c}$ & $52,42 \mathrm{a}$ \\
110 & $16,04 \mathrm{~b}$ & $5,51 \mathrm{~b}$ & $45,80 \mathrm{a}$ \\
NA-151 & $21,30 \mathrm{a}$ & $5,67 \mathrm{~b}$ & $38,87 \mathrm{a}$ \\
NA-189 & $15,80 \mathrm{~b}$ & $5,25 \mathrm{c}$ & $42,88 \mathrm{a}$ \\
Grancam 1277 & $18,95 \mathrm{a}$ & $5,99 \mathrm{~b}$ & $45,62 \mathrm{a}$ \\
0020 & $20,54 \mathrm{a}$ & $6,98 \mathrm{a}$ & $43,21 \mathrm{a}$ \\
0010 & $19,17 \mathrm{a}$ & $5,79 \mathrm{~b}$ & $47,84 \mathrm{a}$ \\
E. pellita & $21,32 \mathrm{a}$ & $5,94 \mathrm{~b}$ & $51,26 \mathrm{a}$ \\
C. torelliana & $15,51 \mathrm{~b}$ & $4,00 \mathrm{~d}$ & $25,42 \mathrm{~b}$ \\
\hline F & $6,0386^{* * *}$ & $5,1200^{* * *}$ & $5,5921^{* * *}$ \\
\hline CV $(\%)$ & 10,92 & 14,78 & 17,17 \\
\hline MG & 18,58 & 5,70 & 44,48 \\
\hline
\end{tabular}

**: significant at the level of $1 \%$ probability $(\mathrm{p}<0.01)$; *: significant at the level of $5 \%$ probability $(0.01=<\mathrm{p}<0.05)$; the averages followed by the same letter does not differ statistically between the Scott-Knott test at 5\% probability; F: $\mathrm{f}$ value calculated in the variance analysis; CV: coefficient of variation; MG: overall average.

**: significativo ao nível de $1 \%$ de probabilidade $(\mathrm{p}<0,01)$; *: significativo ao nível de $5 \%$ de probabilidade $(0,01=<\mathrm{p}<0,05)$; F: valor do $\mathrm{f}$ calculado na análise de variância; CV: coeficiente de variação; MG: média geral. As médias seguidas pela mesma letra não diferem estatisticamente entre si pelo Teste de Scott-Knott ao nível de 5\% de probabilidade. (Table 3).

In the palisade cell thickness (EPP), again, the material Corymbia torelliana showed lower average

In Figure 1, it is understood the difference of dimensions of the leaf tissue between the materials at the cellular level. In Figure 1J, in the material originated of species C. torelliana, it is possible to observe a sheet less thick and with less length of the palisade cell (EPP) in relation to other species.
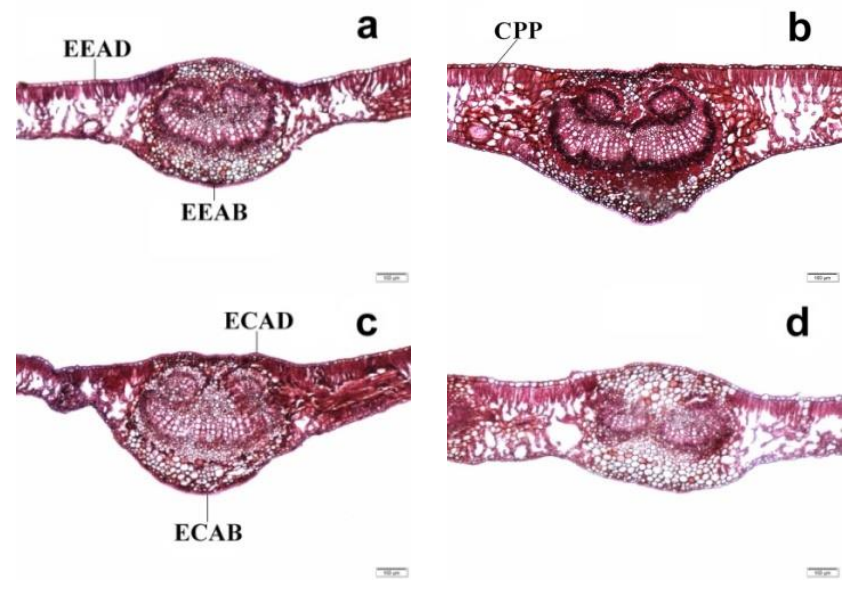

FLORESTA, Curitiba, PR, v. 49, n. 1, p. 021-030, jan/mar.2019

Lisboa.L.A.M. et.al.

Electronic ISSN 1982-4688

DOI: $10.5380 /$ rf.v49i1.52527 

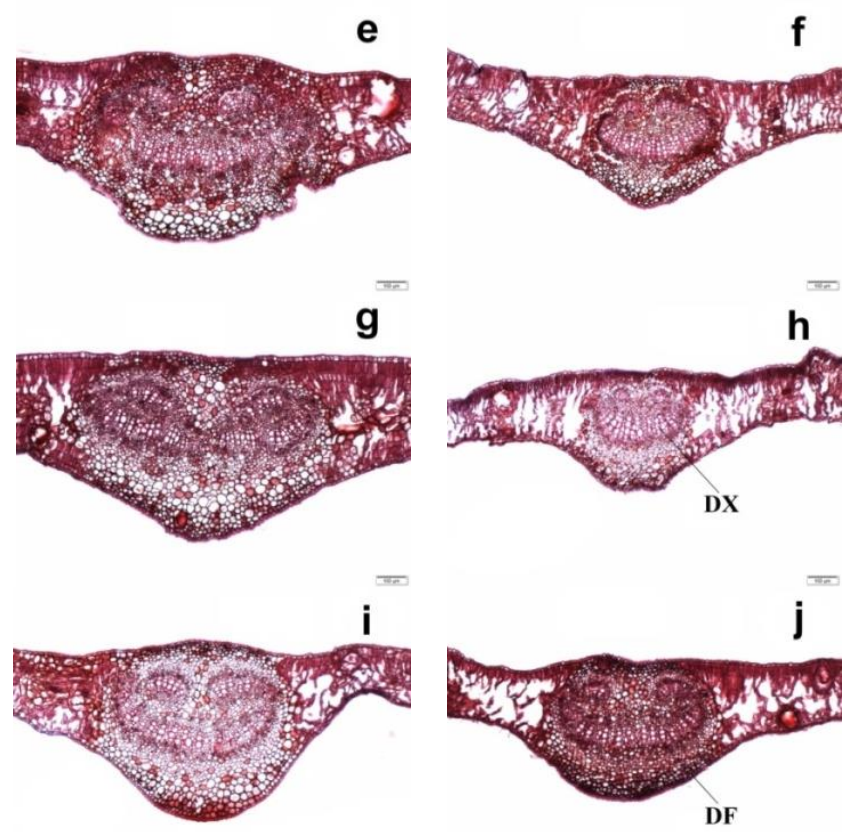

Figure 1. Transverse cuts in the leaves of the genetic materials evidencing the analyzed tissues. ECAD: thickness of the adaxial cuticle; ECAB: abaxial cuticle thickness; EEAD: thickness of the adaxial epidermis; EEAB: thickness of the epidermis abaxial; DX: diameter of xylem; DF: diameter of the phloem; and EPP: thickness of the palisade cell.1A-I: genre Eucalyptus; 1J: genre Corymbia.

Figura 1. Cortes transversais nas folhas dos materiais genéticos evidenciando os tecidos analisados. ECAD: espessura da cutícula adaxial; ECAB: espessura da cutícula abaxial; EEAD: espessura da epiderme adaxial; EEAB: espessura da epiderme abaxial; DX: diâmetro de xilema; DF: diâmetro do floema e EPP: espessura do parênquima paliçádico. 1A-I: gênero Eucalyptus; 1J: gênero Corymbia.

\section{DISCUSSION}

In the parameter diameter at breast height (DAP), the species Corymbia torelliana was the one that was the least outstanding. It is assumed that this response occurs because this material is pure and not hybrid as most of the materials under study. According to Butler et al. (2017), the genetic materials $E$. grandis e $C$. torelliana present chromosomal rearrangement between themselves, although in low rates, which can be coupled to different responses obtained in these parameters for both genera. It is important to emphasize that the species DNA does not always present a considerable relation with the phenotype, being characterized by low heritability.

Reis et al. (2014) report that the planting of Corymbia torelliana species was not accepted in commercial areas due to its poor performance in growth characteristics (AP and DAP), corroborating the data obtained in this study (Table 1).However, for forestry, this species plays a fundamental role at the cross-breeding in order to obtain interspecific hybrids with good performance in volume and quality of wood, which can facilitate its chemical structure degradation in Industrial reactions (HEALEY et al. 2016a; BARBOSA; FILOMENO; Teixeira, 2016; FORD et al., 2011).The authors reported that the selection of superior hybrids, natural or by artificial pollination has taken place on species Corymbia spp., as well as in the species $C$. citriodora; C. variegata (F. Muell.) K. D. Hill \& L. A. S. Johnson, C. henryi (S. T. Blake) K. D. Hill \& L. A. S. Johnson e C. maculata.

The spad index values of this study were similar to those found by Pinkard et al. (2006) when they studied the correlation of the spad index with nitrogen concentration in leaves of plants grown in protected conditions or in the field, which corroborates the results of this work, in which the material that showed the highest index spad revealed the biggest nitrogen content in its leaves (table 1).The same authors also found differences between the species of eucalyptus trees for this chemical element. Sharwood et al (2016), studying the effect of nitrogen in carboxylation of the RuBisCO molecule (ribulose 1.5-bisphosphate Carboxylase oxygenase) in species of Eucalyptus globulus Labill. found that the leaf position in the canopy of the plant and the time taken to collect the material influenced the carboxylative reactions and on leaf ultra structure. 
The material 0010 (Eucalyptus urophilla $\mathrm{x}$ E. grandis) was one of the most outstanding materials in the thickness of the cuticles. However, this advantage did not reflect in its development, as observed in AP and DAP (Table 1), because thicker cuticles provide greater resistance to chemical and physical damages. This is due to its composition being composed primarily of waxy lipids, fatty acids and esters, which increases its impermeability and foliar rigidity. It is important to emphasize that concentrations of these substances may vary, as reported by Racovita and Jetter (2016), which verified values of 1.7 to $1.9 \mu \mathrm{g}^{-1} \mathrm{~cm}^{2}$ wax in the species Phyllostachys aurea Rivière \& C. Rivière (Poaceae).

In an analogous way to the cuticle, the epidermis also plays a role of resistance, acting as a physical barrier to mechanical and herbivory damage of larvae and insects. This happens to be an indication that this feature is one of the most important in the resistance to rust fungus in the family Pucciniaceae (Pucciniapsidii G. Winter), due to the material Eucalyptus pellita presenting greater thickness in the epidermis. As evidenced by Santos et al. (2014), when they had studied the resistance of eucalyptus E. pellita to rust, was verified that the heritability of the resistance to the rust was estimated between $32.7 \% 37.3 \%$. Due to the complexity of the results obtained in their work, the authors had verified that the resistance to the rust has origin related to the greater and minor expression genes.

Regarding the xylem, the results obtained by Santini Júnior et al. (2010), when studying eucalyptus species, were not significant for the thickness and size of the xylem fibers, but it was verified that the species Corymbia torelliana presented the smallest diameter and a smaller number of vessels, corroborating the results of this work. Even if the material $C$. torelliana has presented the lowest foliar ultra structural results, this effect may not interfere in the quality of the wood, because, according to Conti Júnior (2008), the wood of this species can be used in furniture industry and construction by presenting smaller waste and lower rates of cracks (REIS $e t$ al., 2014).

The difference observed in the length Palisade cell (table 3 and Figure 1J) may have triggered fewer chloroplast number, which leads to a less efficient photosynthetic rate, leading to a lesser development of plants, as demonstrated in the table 1.The material $C$. torelliana was the one which presented the smallest medium for the AP and DAP parameters. Still, this smaller development can be coupled to the smaller caliber of the phloem (table 3 and Figure 1J), leading to a lower efficiency in the distribution of photoassimilate.

The anatomical characteristics of a leaf or even its chemical composition present variability between trees of the same species or even in their cross-breedings, not demonstrating a unique pattern among the studied materials (OLIVEIRA et al., 2012; TREVISAN et al., 2013). Morphologically, one of the features presented by the leaves exposed to the Sun is the adequacy in relation to their surface and their volume, i.e., they present less leaf area with greater thickness. This way, they are smaller and heavier per unit of area in relation to the ones cultivated in the shade (ARAGÃO et al., 2014; BÜNDCHEN et al., 2015).

However, the levels of one exactly organism can present anatomical differences between the ones which situates in the superior portion of the crown and the ones of the inferior portion, due to radiation intensity that reaches them (PIRES et al., 2015).Therefore, it is fundamental the understanding of leaf plasticity and its ultra structural dimensions in the tissues, due to its specific characteristics performed in the vegetal organs, that are directly related to its way of development (BRYANT; TRUEMAN, 2015).

\section{CONCLUSIONS}

- The materials NA - 151 (Eucalyptus urophilla x E. grandis) and Grancam 1277 (E. grandis x E. camaldulensis) presented higher plant hight (AP).

- The materials 0020 (Eucalyptus saligna), 0010 (E. resinífera) and Corymbia torelliana presented smaller diameter at breast height (DAP).

- In general, the genetic material Corymbia torelliana presented the lowest values to the evaluated foliar ultra structural parameters.

\section{REFERENCES}

ARAGÃO, D. de S.; LUNZ, A. M. P.; de OLIVEIRA, L. C.; RAPOSO, A.; FERMINO JUNIOR, P. C. P. Efeito do sombreamento na anatomia foliar de plantas jovens de andiroba (Carapaguianensis Aubl.). Revista Árvore, Viçosa, v. 38, n. 4, p.631-639, 2014.http://dx.doi.org/10.1590/S0100-67622014000400006

BARBOSA, L. C. A.; FILOMENO, C. A.; TEIXEIRA, R. R. Chemical variability and biological activities of $\begin{array}{llllllll}\text { Eucalyptus } & \text { spp. essential oils.Molecules, } \quad \text { v. } \quad 21, \quad \text { n. } \quad 1671, \quad \text { p. } & 2-33, & 2016 .\end{array}$ http://dx.doi.org/10.3390/molecules21121671

FLORESTA, Curitiba, PR, v. 49, n. 1, p. 021-030, jan/mar.2019

Lisboa.L.A.M. et.al.

Electronic ISSN 1982-4688

DOI: $10.5380 /$ rf.v49i1.52527 
BRYANT, P. H; TRUEMAN, S. J. Stem Anatomy and Adventitious Root Formation in Cuttings of Angophora, Corymbia and Eucalyptus.Forests, Basel, v. 6, p. 1227-1238, 2015. http://dx.doi.org/10.3390/f6041227

BÜNDCHEN, M.; BOEGER, M. R. T.; REISSMANN, C. B. Estrutura foliar de espécies lenhosas de dossel e sub-bosque em uma floresta subtropical do sul do Brasil. Iheringia, Série Botânica, Porto Alegre, v. 70, n. 1, p.105-114, 2015.

BUTLER, J. B.; VAILlANCOURT, R. E.; POTTS, B. M.; LEE, D. J.; KING, G. J.; BATEN, A.; SHEPHERD, M.; FREEMAN, J. Comparative genomics of Eucalyptus and Corymbia reveals low rates of genome structural rearrangement.BMC genomics, Londres, v. 18, n. 1, p.397, 2017.

CARLQUIST, S. Ecological estrategies of xylem evolution.Berkeley:University of California Press, 1975,259 p.

CONTI JUNIOR, José Luiz Ferraresso; FACCO, Luis Eduardo; GARCIA, José Nivaldo.Espécies de Eucalyptus Potenciais para Produção de Madeira Serrada. Anais... São Paulo: [s.n.], 2008.

DONATO, A. M.; MORRETES, B. L. de.Anatomia foliar de Eugenia florida DC.(Myrtaceae). Revista Brasileira de Farmacognosia, São Paulo, v. 19, n. 3, p.759-770, 2009.http://dx.doi.org/10.1590/S0102$\underline{695 \times 2009000500019}$

Genetic gain from different selection methods in Eucalyptus macarthurii progenies in different environments.Cerne, Lavras, v. 22, n. 3, p. 299-308, 2016. http://dx.doi.org/10.1590/01047760201622032197

EMPRESA BRASILEIRA DE PESQUISA AGROPECUÁRIA (Embrapa).Centro Nacional de Pesquisa dos Solos.Sistema brasileiro de classificação de solos.Rio de Janeiro:EMBRAPA/CNPS, 2013. 353 p.

FIGUEIREDO, F. A. M. M. A.; CARNEIRO, J. G. A.; PENCHEL, R. M.; BARROSO, D. G.; DAHER, R. F. Efeito das variações biométricas de mudas clonais de eucalipto sobre o crescimento no campo.Revista Árvore, Viçosa, v.35, n.1, p.111, 2011. http://dx.doi.org/10.1590/S0100-67622011000100001

HEALEY, A. L.; LEE, D. J.; LUPOI, J. S.; PAPA, G.; GUENTHER, J. M.; CORNO, L.; ADANI, F.; SINGH, S.; SIMMONS, B. A.; HENRY, R. J. Evaluation of relationships between growth rate, tree size, lignocellulose composition, and enzymatic saccharification in interspecific Corymbia Hybrids and parental taxa.Frontiers Plant Science, Lausanne, v. 7, p. 1-14, 2016a. http://dx.doi.org/10.3389/fpls.2016.01705

HEALEY, A. L.; LUPOI, J. S.; LEE, D. J.; SYKES, R. W.; GUENTHER, J. M., TRAN, K.; DECKER S. R.; SINGH, S.; SIMMONS, B. A.; HENRY, R. J. Effect of aging on lignin content, composition and enzymatic saccharification in Corymbia hybrids and parental taxa between years 9 and 12. Biomass and Bioenergy, Paris, v. 93, p. 50-59, 2016b.https://doi.org/10.1016/j.biombioe.2016.06.016

KRAUS, J. E.; ARDUIN, M. Manual básico de métodos em morfologia vegetal. Seropédia: EDUR, 1997.198 p.

OLIVEIRA, B. R. U. de; LATORRACA, J. V. de F.; TOMAZELlO FILHO, M.; PALERMO, G. P. de M; CARVALHO, A. M. de; PASTRO, M. S. Microdensitometria de Raios X aplicada na determinação da variação da densidade do lenho de árvores de Eucalyptus grandis W. Hill. Scientia Forestalis, Piracicaba, v. 40, n. 93, p.103-112, 2012.

PINKARD, E. A.; PATEL, V.; MOHAMMED, C. Chlorophyll and nitrogen determination for plantation-grown Eucalyptus nitens and E. globulus using a non-destructive meter.Forest Ecology and Management, v.223, p. 211-217, 2006. https://doi.org/10.1016/j.foreco.2005.11.003

PIRES, M. F.; PEREIRA, M. P.; CASTRO, E. M. de; BARBOSA, S.; PEREIRA, F. J. Micromorfometria foliar de Schinusmolle L. (Anarcadiaceae) em diferentes alturas na copa. Cerne, Lavras, v. 21, n. 1, p.17-25, 2015. http://dx.doi.org/10.1590/01047760201521011530

RACOVITA, R. C.; JETTER, R. Composition of the epicuticular waxes coating the adaxial side of Phyllostachys aurea leaves: Identification of very-long-chain primary amides.Phytochemistry, v. 130, p. 252-261, 2016. http://dx.doi.org/10.1016/j.phytochem.2016.06.005

RAIJ, B. van; CANTARELlA, H.; QUAGGIO, J.A.; FURLANI, A.M.C. Recomendações de adubação e calagem no Estado de São Paulo. 2.ed.Campinas Instituto Agronômico, 1996. 300p. 
REIS, C. A. F; ASSIS, T. F. de; SANTOS, A. M.; PALUDZYSZYN FILHO, E. Corymbia torelliana: estado da arte de pesquisas no Brasil. Colombo: Embrapa Florestas, 2014. 48p. (Documentos, n. 261).

SANTINI JÚNIOR, L.; LIMA, I. L.; BUFOLO, A.; MOURA, A. E. de; BIBINI, G. LONGUI, E. L.; FLORSHEIM, S. M. B. Densidade básica e dimensões celulares em diferentes espécies de Eucalyptus L'Herit., plantadas em Itatinga/SP.IF. Série Registros, São Paulo, n. 42, p.15-21, 2010.(IF. Série registros).

SANTOS, M. R.; GUIMARÃES, L. M. da S.; RESENDE, M. D. V. de; ROSSE, L. N.; ZAMPROGNO, K. C.; ALFENAS, A. C. Resistance of Eucalyptus pellita torust (Pucciniapsidii).Crop Breeding and Applied Biotechnology, v. 14, p. 244-250, 2014. http://dx.doi.org/10.1590/1984-70332014v14n4a38

SHARWOOD, R. E.; CROUS, K. Y.; WHITNEY, S. M.; ELLSWORTH, D. D.; GHANNOUM, O. Linking photosynthesis and leaf $\mathrm{N}$ allocation under future elevated $\mathrm{CO} 2$ and climate warming in Eucalyptus globulus.Journal of Experimental Botany, Lancaster, p. 1-11, 2016. https://doi.org/10.1093/jxb/erw484

SILVA, F. de A.S. e.; AZEVEDO, C.A.V. de. The Assistat Software Version 7.7 and its use in the analysis of experimental data.African Journal Agriculture Resarch, v. 11, n. 39, p. 3733-3740, 2016. http://dx.doi.org/10.5897/AJAR2016.11522

TREVISAN, R.; SOUZA, J. T. de; DENARDI, L.; HASELEIN, C. R.; SANTINI, E. J. Efeito do desbaste no comprimento das fibras da madeira de Eucalyptus grandis W. Hill ex Maiden. Ciência Florestal, Santa Maria, v. 23, n. 2, p.461-473, 2013.http://dx.doi.org/10.5902/198050989290 
FLORESTA, Curitiba, PR, v. 49, n. 1, p. 021-030, jan/mar.2019 Lisboa.L.A.M. et.al. 